\title{
Pengembangan Buah dan Sayur Organik Sebagai Oleh-Oleh Wisata Daerah Pegunungan
}

Istijabatul Aliyah, Bambang Pujiasmanto

Department of Urban and Regional Planning, Faculty of Engineering, Sebelas Maret University, Indonesia

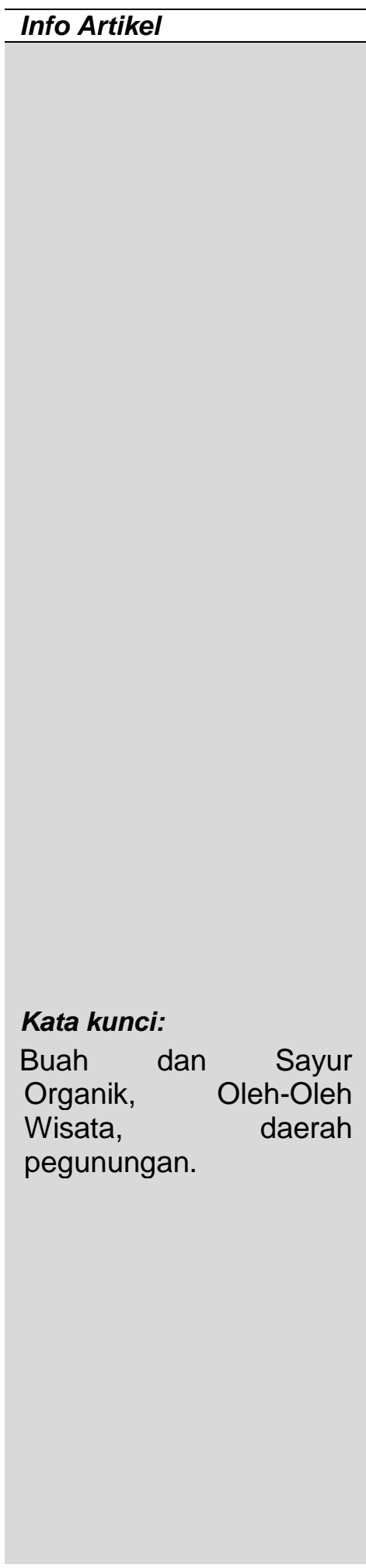

E-mail: istijabatul@ft.uns.ac.id

\begin{abstract}
Mountainous areas have a lot of tourism potential, including organic agriculture-based agro-tourism. However, there are still some problems faced by the farming community such as limited skills regarding processing of agricultural products in the form of organic fruits and vegetables as souvenirs typical of mountain tourism. limitation of packaging creativity that meets the health and safety feasibility standards of organic fruits and vegetables as tourist souvenirs that are easily carried by tourists, and marketing of agricultural products in the form of organic fruits and vegetables to attract tourists and the wider community. The methods to be used include methods counseling and training as a means of transfer of knowledge about the processing, packaging and marketing of organic agriculture and the ins and outs of which will be provided to partners, assistance methods to enhance partners' creativity and performance in processing, packaging and marketing agricultural products in the form of organic fruit and vegetables as souvenirs for tourism typical of mountainous areas in the economic development of society and regional tourism, and the provision of packaging equipment to implement packaging that meets hygiene, health and food safety standards, and the creation of a website as a medium for expanding the network to improve a tourist attraction. The targeted results are an increase in skills in processing, packaging, and marketing agricultural products in the form of organic fruit and vegetables as souvenirs typical of mountain tourism, diversification of processed organic plant products as souvenirs typical of an area, the addition of facilities in the form of packaging tools (wrapping mechine) for packaging organic fruits and vegetables so that they are easy to carry as souvenirs for a typical tourist area, the expansion of marketing networks
\end{abstract}

\section{Abstrak}

Daerah pegunungan memiliki banyak potensi wisata, termasuk agrowisata berbasis pertanian organik. Namun masih terdapat beberapa permasalahan yang dihadapi oleh masyarakat petani seperti keterbatasan keterampilan mengenai pengolahan hasil pertanian berupa buah dan sayur organik sebagai oleh-oleh wisata khas daerah pegunungan. keterbatasan kreativitas pengemasan yang memenuhi standar kelayakan kesehatan dan keamanan buah dan sayur organik sebagai oleh-oleh wisata yang mudah dibawa oleh para wisatawan, dan pemasaran hasil pertanian berupa buah dan sayur organik untuk menjadi daya tarik wisatawan dan masyarakat luas.Metode yang akan digunakan meliputi metode penyuluhan dan pelatihan sebagai alat transfer pengetahuan tentang pengolahan, pengemasan dan pemasaran pertanian organik dan seluk beluknya yang akan diberikan kepada mitra, metode pendampingan untuk meningkatkan kreativitas dan kinerja mitra dalam mengolah, mengemas dan memasarkan produk pertanian berupa buah dan sayur organik sebagai oleh-oleh wisata khas daerah pegunungan 


\begin{abstract}
dalam pengembangan ekonomi masyarakat dan pariwisata daerah, dan pemberian bantuan peralatan pengemasan untuk mengimplementasikan pengemasan yang memenuhi standard kebersihan, kesehatan, dan keamanan pangan, serta pembuatan website sebagai media perluasan jejaring untuk meningkatkan daya tarik wisata.Hasil yang ditargetkan adalah adanya peningkatan ketrampilan dalam mengolah, mengemas, dan memasarkan produk pertanian berupa buah dan sayur organik sebagai oleh-oleh wisata khas daerah pegunungan, diversifikasi produk olahan tanaman organik sebagai oleh-oleh wisata khas suatu daerah, penambahan fasilitas berupa alat-alat pengemasan (wrapping mechine) untuk pengemasan buah dan sayur organik agar mudah dibawa sebagai oleh-oleh wisata khas suatu daerah, perluasan jejaring pemasaran.
\end{abstract}

\title{
PENDAHULUAN
}

Kabupaten Karanganyar merupakan salah satu kabupaten di Propinsi Jawa Tengah yang terletak di daerah perbatasan antara Propinsi Jawa Tengah dan Jawa Timur. Lokasi Ibukota Kabupaten Karanganyar berada sekitar $15 \mathrm{Km}$ dari Kota Surakarta (lokasi Universitas Sebelas Maret). Wilayah Kabupaten Karanganyar berbatasan dengan Kabupaten Wonogiri di sebelah selatan, Kota Surakarta, Kabupaten Sukoharjo dan Kabupaten Boyolali di sebelah barat, Kabupaten Sragen di sebelah utara, dan Kabupaten Magetan Propinsi Jawa Timur di sebelah timur (Badan Statistik Kabupaten Karanganyar, 2013).

Pemerintah Kabupaten Karanganyar telah lama menggencarkan program pembangunan pertanian, kepariwisataan, dan industri bagi masyarakatnya. Program ini antara lain dapat dilihat dari slogan pembangunan daerah Kabupaten Karanganyar yakni INTANPARI (Industri, Pertanian, dan Pariwisata). Pertanian di wilayah ini telah berkembang pesat dan telah memberikan kontribusi kepada pengembangan ekonomi daerah. Hal ini didukung oleh banyaknya sumber daya pertanian dalam arti luas termasuk peternakan, perikanan, perkebunan, serta kehutanan yang memiliki potensi untuk mendukung peningkatan perekonomian dan kesejahteraan masyarakat. Hal ini dikarenakan pengembangan sumber daya pertanian di wilayah tersebut telah menciptakan berbagai peluang usaha yang dapat dilakukan oleh masyarakat (BAPPEDA Kab. Karanganyar, 2013).

Di sisi lain akhir-akhir ini telah terjadi pergeseran pola pikir (mindset) masyarakat tentang kesehatan menuju pola konsumsi makanan sehat seperti makanan pokok (beras), buah, sayur, dan lauk pauk dari ikan, daging sapi maupun kambing yang bebas dari pestisida dan zat berbahaya lainnya. Dengan kata lain masyarakat telah semakin cerdas dan selektif dalam hal pola makan dengan memilih bahan konsumsi yang berasal dari pertanian organik. Di samping mendukung upaya untuk mewujudkan hidup sehat melalui konsumsi produk pertanian organik, pengembangan pertanian organik juga menunjang pembangunan yang ramah lingkungan.

Beberapa daerah telah berupaya mengembangkan pertanian organik. Selain untuk menjawab kebutuhan masyarakat terhadap makanan sehat yang terbebas dari bahan kimia, kegiatan pertanian organik di kawasan pedesaan juga dapat menjadi daya tarik dan kegiatan wisata. Kabupaten Karanganyar merupakan salah satu daerah yang telah menginisiasi pengembangan pertanian organik dengan 
memotivasi masyarakat petani di daerah pedesaan agar menanam berbagai jenis tanaman dan mengelolanya berdasarkan konsep pertanian organik. Bahkan juga telah dilakukan upaya untuk sekaligus mempersiapkan desa-desa tersebut, termasuk Desa Berjo, menjadi kawasan wisata minat khusus dengan mengandalkan pada potensi pertanian organik. Produk pertanian organik diharapkan mampu menjadi daya tarik bagi konsumen sehingga mendukung upaya pengembangan ekonomi kreatif bagi masyarakat pedesaan yang diharapkan dapat meningkatkan kesejahteraan mereka.

Namun demikian, masih terdapat beberapa permasalahan di dalam mengembangkan pertanian organik di desa wisata Berjo Kabupaten Karanganyar tersebut. Meskipun telah sering menggunakan istilah organik namun banyak diantara para pelaku, utamanya petani, yang belum mengetahui secara pasti atau belum memiliki pengetahuan yang utuh dan memadai mengenai pertanian organik, khususnya dalam mengolah, mengemas, dan memasarkan hasil pertanian berupa buah dan sayur organik sebagai oleh-oleh wisata khas Desa Berjo. Sebagian besar warga yang terlibat di dalam pelaksanaan pertanian organik lebih banyak mengetahui secara permukaan atau hanya dalam penggunaan label organik saja. Di samping itu masyarakat petani juga belum memiliki daya kreativitas yang memadai untuk melakukan diversifikasi produk pertanian organik, khususnya untuk dikaitkan dengan pengembangan pariwisata berbasis sumber daya pertanian atau agrowisata.

Oleh karena itu berdasarkan beberapa permasalahan di atas, diperlukan adanya intervensi dari pihak terkait, termasuk perguruan tinggi, untuk memberikan bekal pengetahuan dan keterampilan kepada warga masyarakat, utamanya petani, agar mereka memiliki pengetahuan dan keterampilan yang baik mengenai pertanian organik dan seluk beluknya sehingga dapat mengelola, mengemas, dan memasarkan hasil pertanian buah dan sayur organik dengan baik dan tepat. Dengan modal pengetahuan dan keterampilan yang baik mengenai pertanian organik, masyarakat petani diharapkan dapat menyajikan layanan kepada wisatawan dan masyarakat luas dalam bentuk berbagai produk pertanian organik, baik yang langsung seperti beras, sayuran, buah, dan tanaman pot yang portable (mudah dibawa) sebagai oleh-oleh, maupun yang tidak langsung seperti makanan olahan berbasis hasil pertanian organik. Kegiatan PKM Pengembangan Buah Dan Sayur Organik Sebagai Oleh-Oleh Wisata Khas Desa Berjo Kecamatan Ngargoyoso Kabupaten Karanganyar Propinsi Jawa Tengah ini diarahkan untuk mengatasi berbagai permasalahan tersebut.

Gambar 1: Lahan pertanian di Kabupaten Karanganyar.
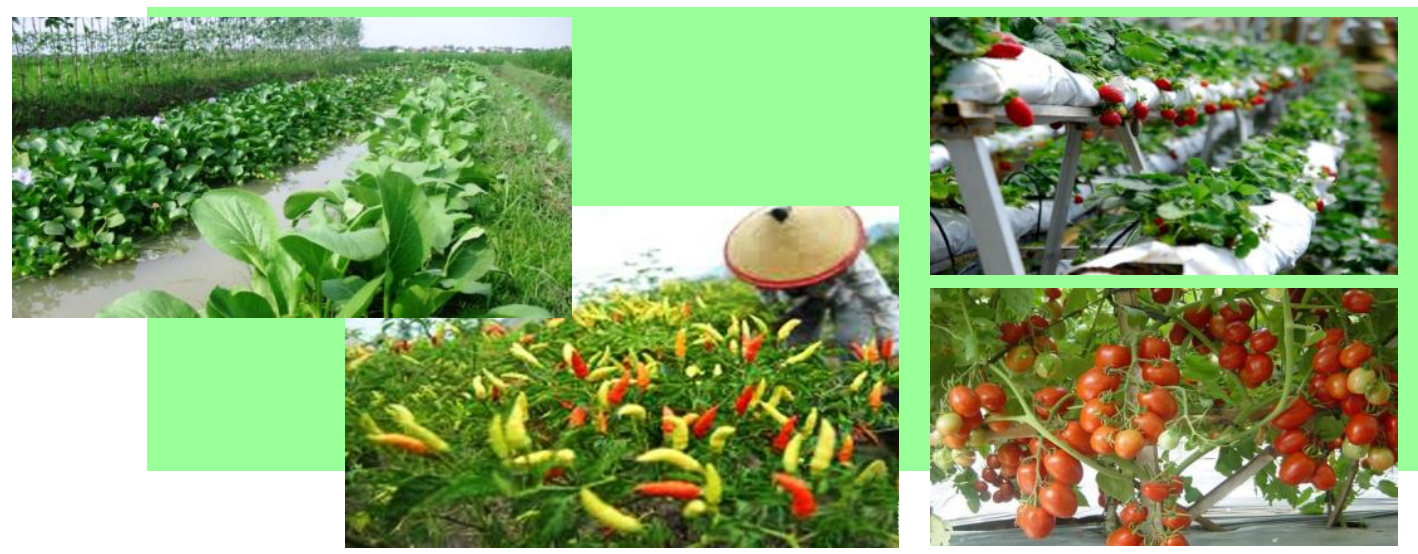


\section{METODE PENELITIAN}

\section{Persoalan prioritas mitra}

Beberapa persoalan yang dihadapi oleh mitra (Kelompok Usaha Tani "Gemah Ripah" dan "Sumber Rejeki") di Desa Berjo Kecamatan Ngargoyoso Kabupaten Karanganyar adalah Keterbatasan pengetahuan dan keterampilan yang berkaitan dengan pengolahan, pengemasan, dan pemasaran hasil pertanian berupa buah dan sayur organik sebagai oleh-oleh wisata khas Desa Berjo Kecamatan Ngargoyoso Kabupaten Karanganyar Propinsi Jawa Tengah; Keterbatasan kreativitas mengolah dalam berbagai ragam produk hasil pertanian buah dan sayur organik sebagai oleh-oleh wisata khas Desa Berjo Kecamatan Ngargoyoso Kabupaten Karanganyar Propinsi Jawa Tengah yang mudah dibawa oleh para wisatawan; Keterbatasan peralatan pengemasan yang sesuai standard kebersihan, kesehatan dan keamanan pangan serta yang dapat menarik minat wisatawan; dan Keterbatasan manajemen pemasaran dan jejaring untuk meningkatkan daya tarik wisata organik Desa Berjo Kecamatan Ngargoyoso Kabupaten Karanganyar Propinsi Jawa Tengah. Selama ini ke dua kelompok usaha pertanian organik tersebut masih mengandalkan pengetahuan tradisional dan bersifat ala kadarnya. Ke depan kedua kelompok usaha pertanian organik tersebut menginginkan untuk dapat meningkatkan pengetahuan dan keterampilan dalam melaksanakan kegiatan pertanian buah dan sayur organik sehingga hasilnya dapat memenuhi standar kesehatan dan kelestarian lingkungan. Dalam hal ini kegiatan PKM Pengembangan Buah dan Sayur Organik sebagai Oleh-Oleh Wisata Khas Desa Berjo Kabupaten Karanganyar Propinsi Jawa Tengah sesuai untuk dilaksanakan karena akan bermanfaat dalam memberikan solusi terhadap permasalahan yang dihadapi oleh kelompok usaha tani "Gemah Ripah" dan "Sumber Rejeki".

2. Justifikasi pengusul bersama mitra dalam menentukan persoalan prioritas yang disepakati untuk diselesaikan selama pelaksanaan program PKM

Penentuan persoalan prioritas telah disepakati oleh pihak mitra, dalam hal ini adalah Kelompok Usaha Tani "Gemah Ripah" dan "Sumber Rejeki" dengan Tim Pengusul PKM dari Pusat Studi Penelitian dan Pengembangan Pariwisata (PUSPARI) LPPM Universitas Sebelas Maret untuk diselesaikan bersama selama pelaksanaan program kemitraan masyarakat (PKM Pengembangan Buah dan Sayur Organik sebagai Oleh-Oleh Wisata Khas Desa Berjo Kabupaten Karanganyar Propinsi Jawa Tengah). Persoalan utama yang berupa kendala untuk meningkatkan kompetensi di dalam melaksanakan kegiatan pertanian organik telah dirumuskan menjadi beberapa bidang yang akan ditindaklanjuti melalui kegiatan PKM pada tahun 2018. Bidang-bidang tersebut adalah pengetahuan tentang pengolahan, pengemasan, dan pemasaran produk pertanian buah dan sayur organik, diversifikasi produk olahan buah dan sayur organik, fasilitasi peralatan pengemasan hasil pertanian buah dan sayur organik, pembuatan website sebagai media perluasan jejaring pemasaran hasil pertanian buah dan sayur organik sebagai oleh-oleh wisata khas desa Berjo, dalam mendukung pengembangan wisata organik di Desa Berjo Kecamatan Ngargoyoso Kabupaten Karanganyar.

\section{Metode Pendekatan yang Ditawarkan untuk menyelesaikan persoalan yang}

\section{dihadapi mitra}

Metode pendekatan untuk menyelesaikan permasalahan yang dihadapi mitra (Kelompok Usaha Tani "Gemah Ripah" dan "Sumber Rejeki" ditentukan berdasarkan kesepakatan antara mitra dengan Tim PKM "Pengembangan Buah dan Sayur Organik sebagai OlehOleh Wisata Khas Desa Berjo Kabupaten Karanganyar Propinsi Jawa Tengah" dari Tim Pengusul PKM dari PUSPARI LPPM Universitas Sebelas Maret adalah memberikan penyuluhan, pelatihan, pendampingan, dan bantuan fasilitas sesuai kapasitas program PKM untuk meningkatkan pengetahuan dan keterampilan mitra (UKM) dalam mengembangkan pertanian buah dan sayur organik sebagai oleh-oleh wisata khas Desa 
Berjo agar hasil pertanian yang dihasilkan dapat memenuhi standar kesehatan bagi konsumen dan ramah terhadap lingkungan.

Metode yang diterapkan meliputi beberapa bagian :

a. Tahapan proses pengolahan, dalam peningkatan pengetahuan dan ketrampilan pengolahan, diberikan pelatihan dan pendampingan pembuatan aneka ragam makanan kripik dan kue dari buah dan sayur organik, minuman segar buah dan sayur organik, dan buah dan sayur organik dalam bentuk yang masih utuh, serta bibit tanaman buah dan sayur organik yang dapat ditanam. Semua hasil diversifikasi produk olahan dikemas dalam bentuk yang mudah untuk dibawa sebagai oleh-oleh wisata khas Desa Berjo.

Gambar 4: Berbagai Contoh Olahan Produk Pertanian Buah dan Sayur Organik Yang Dapat diterapkan di Desa Berjo
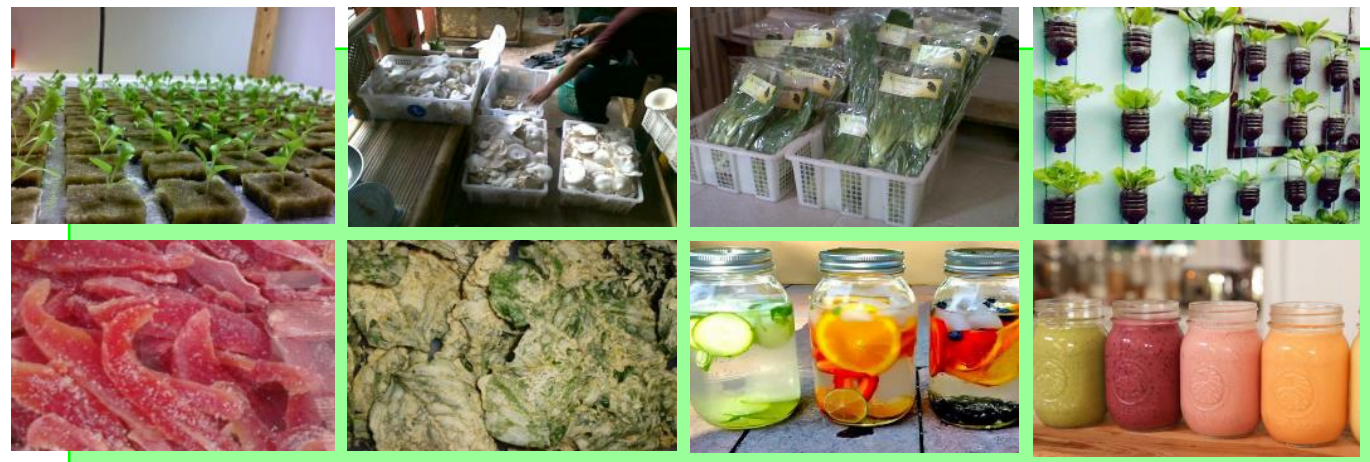

b. Pengemasan produk pertanian buah dan sayur organik dengan peralatan mesin dan berbagai alat penunjang lainnya yang dapat menghasilkan oleh-oleh wisata khas Desa Berjo sesuai dengan standard kebersihan, kesehatan dan keamanan pangan. Pengemasan produk tertentu perlu menggunakan wrapping mechine, tetapi adapula produk yang menggunakan teknik pengemasan dengan manual. Disamping itu, diperlukan pula pengemasan dengan menggunakan pot tanaman baik yang vertikal maupun horizontal.

Gambar 5: Peralatan Yang Diperbantukan Untuk UKM

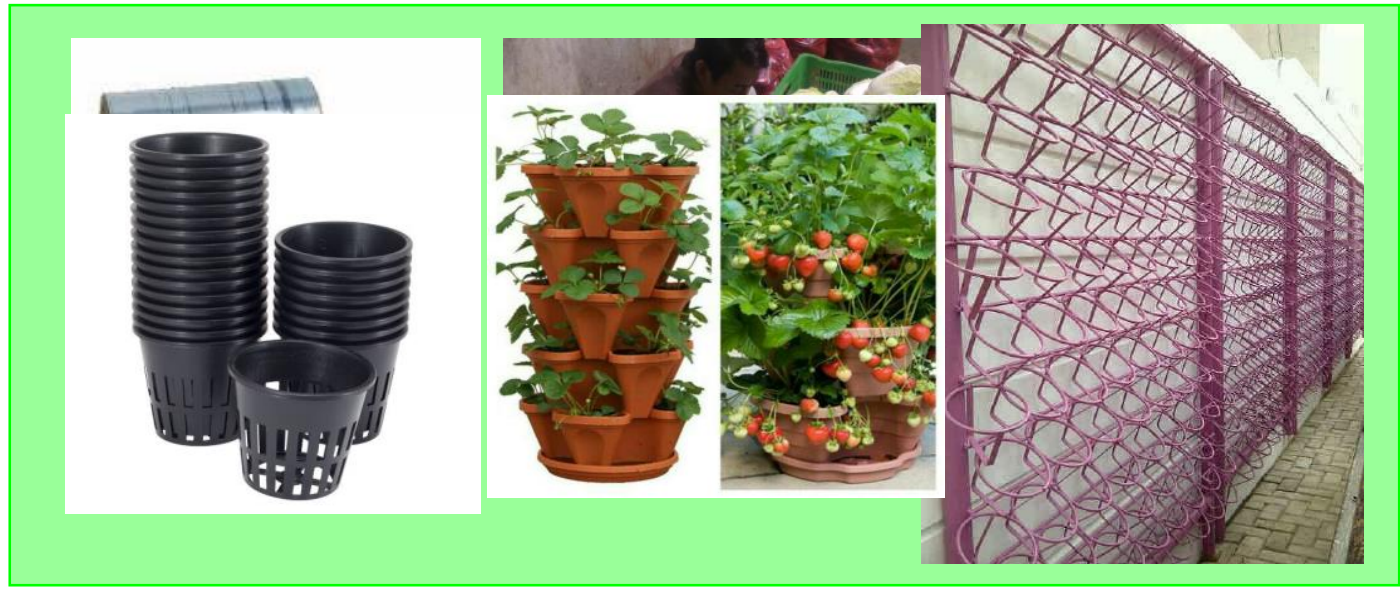

c. Perluasan jejaring pemasaran dilakukan dengan pembuatan website untuk mempublikasikan, menginformasikan, dan mempromosikan keunikan wisata organik di Desa Berjo, dengan berbagai ragam komoditas produk pertanian organik, bentuk paket wisata pendidikan pertanian organik, wisata alam sightseeing pertanian 
organic, dan wisata kuliner berbagai produk olahan pertanian buah dan sayur organik, serta berbagai fasilitas penunjang yang ada di Desa Berjo.

Gambar 6: Contoh Website Pemasaran Wisata Pertanian

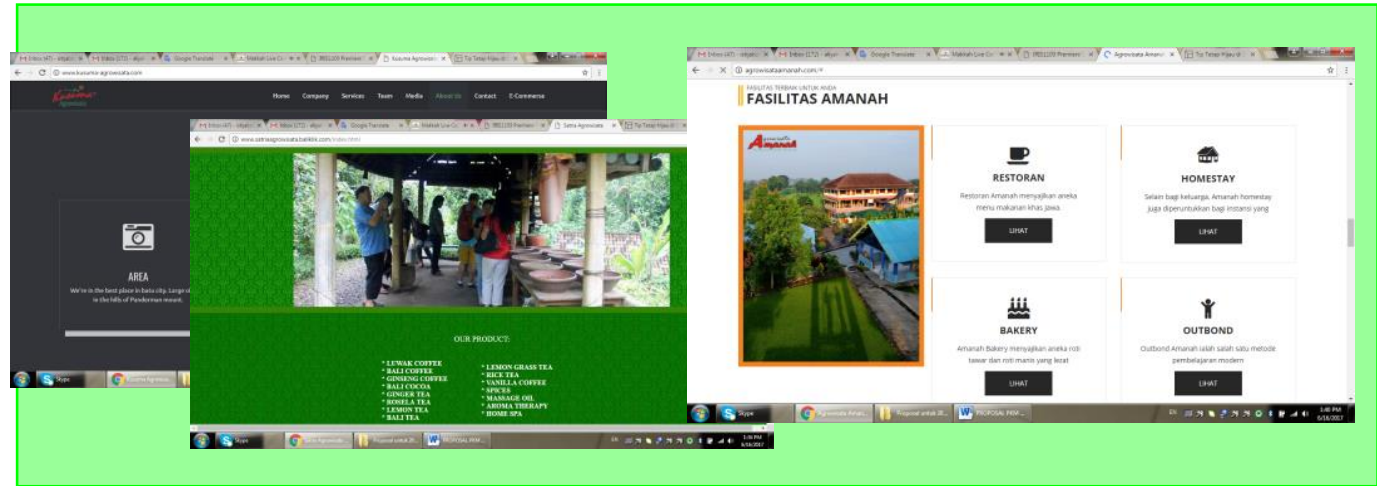

\section{Prosedur Kerja untuk mendukung realisasi metode yang ditawarkan}

a. Tempat dan Waktu

Kegiatan ini akan dilakukan di 2 (dua) lokasi, yakni di Kelompok Usaha Tani "Gemah Ripah" yang berlokasi di Dusun Berjo Desa Berjo Kecamatan Ngargoyoso Kabupaten Karanganyar dan Kelompok Usaha Tani "Sumber Rejeki" yang berlokasi di Dusun Berjo Desa Berjo Kecamatan Ngargoyoso Kabupaten Karanganyar. Waktu pelaksanaan kegiatan direncanakan selama delapan bulan (April-Nopember 2016).

b. Metode Pelaksanaan

Metode yang digunakan dalam implementasi kegiatan PKM ini meliputi: penyuluhan (untuk memberikan wawasan dan meningkatkan pengetahuan) mengenai wisata pertanian organik, pelatihan (untuk meningkatkan keterampilan) yang berkaitan dengan menciptakan oleh-oleh wisata yang memiliki keunikan Desa Berjo, dan pengembangan pengemasan dan pemasaran produk hasil pertanian buah dan sayur organik sebagai oleh-oleh wisata khas desa Berjo. Langkah-langkah (prosedur dan rencana kegiatan) dalam implementasi kegiatan PKM ini dapat dilihat pada Tabel 7.

Tabel 7: Metode Pelaksanaan Kegiatan PKM.

\begin{tabular}{|l|l|l|}
\hline NO. & \multicolumn{1}{|c|}{ IMPLEMENTASI } & \multicolumn{1}{c|}{$\begin{array}{l}\text { METODE PENDEKATAN DAN TAHAPAN } \\
\text { PELAKSANAAN }\end{array}$} \\
\hline 1 & $\begin{array}{l}\text { Penyuluhan dan pelatihan } \\
\text { tentang pengolahan, } \\
\text { pengemasan dan } \\
\text { pemasaran produk hasil } \\
\text { pertanian buah dan sayur } \\
\text { organik }\end{array}$ & $\begin{array}{l}\text { Tim PKM Pengembangan Buah dan Sayur Organik } \\
\text { sebagai Oleh-Oleh Wisata Khas Desa Berjo } \\
\text { Kabupaten Karanganyar Propinsi Jawa Tengah } \\
\text { memberikan penyuluhan mengenai pengetahuan } \\
\text { dan hal-hal yang berkaitan pengolahan, } \\
\text { pengemasan dan pemasaran produk hasil } \\
\text { pertanian buah dan sayur organik. }\end{array}$ \\
\hline $\mathbf{2}$ & $\begin{array}{l}\text { Pendampingan tentang } \\
\text { pengolahan, pengemasan } \\
\text { dan pemasaran produk } \\
\text { hasil pertanian buah dan } \\
\text { sayur organik }\end{array}$ & $\begin{array}{l}\text { Tim PKM Pengembangan Buah dan Sayur Organik } \\
\text { sebagai Oleh-Oleh Wisata Khas Desa Berjo } \\
\text { Kabupaten Karanganyar Propinsi Jawa Tengah } \\
\text { memberikan pendampingan untuk meningkatakn } \\
\text { ketrampilan dan kinerja terkait dengan pengolahan, }\end{array}$ \\
\hline
\end{tabular}




\begin{tabular}{|l|l|l|}
\hline 3 & $\begin{array}{l}\text { pengemasan, dan pemasaran produk hasil } \\
\text { pertanian buah dan sayur organik sebagai oleh- } \\
\text { oleh wisata khas Desa Berjo. }\end{array}$ \\
\hline $\begin{array}{l}\text { Pemberian bantuan } \\
\text { peralatan pengolahan, } \\
\text { pengemasan dan } \\
\text { pemasaran produk hasil } \\
\text { pertanian buah dan sayur } \\
\text { organik }\end{array}$ & $\begin{array}{l}\text { Tim PKM Pengembangan Buah dan Sayur Organik } \\
\text { sebagai Oleh-Oleh Wisata Khas Desa Berjo } \\
\text { Kabupaten Karanganyar Propinsi Jawa Tengah } \\
\text { memberikan bantuan peralatan pengolahan, } \\
\text { pengemasan dan pemasaran produk hasil pertanian } \\
\text { buah dan sayur organik agar sesuai dengan } \\
\text { standard kebersihan, kesehatan, dan keamanan } \\
\text { pangan.. }\end{array}$ \\
\hline $\mathbf{4}$ & $\begin{array}{l}\text { Pembuatan Website untuk } \\
\text { perluasan jejaring } \\
\text { pemasaran produk } \\
\text { pertanian buah dan sayur } \\
\text { organik }\end{array}$ & $\begin{array}{l}\text { Tim PKM Pengembangan Buah dan Sayur Organik } \\
\text { sebagai Oleh-Oleh Wisata Khas Desa Berjo } \\
\text { Kabupaten Karanganyar Propinsi Jawa Tengah } \\
\text { membuatkan website untuk perluasan jejaring } \\
\text { pemasaran produk hasil pertanian buah dan sayur } \\
\text { organik. }\end{array}$ \\
\hline
\end{tabular}

\section{Partisipasi mitra dalam pelaksanaan Program Kemitraan Masyarakat}

Dalam melaksanakan program PKM ini pihak mitra (Kelompok Usaha Tani "Gemah Ripah" dan "Sumber Rejeki") menyatakan bersedia berpartisipasi aktif dalam pelaksanaan program "PKM Pengembangan Buah dan Sayur Organik sebagai Oleh-Oleh Wisata Khas Desa Berjo Kabupaten Karanganyar Propinsi Jawa Tengah" ini khususnya untuk mengikuti penyuluhan, pelatihan, dan pendampingan untuk meningkatkan kompetensi mereka dalam rangka mengelola dan mengembangkan pertanian organik agar mereka dapat menghasilkan produk pertanian yang berkualitas dalam kontek demand dimana produk pertanian yang dihasilkan benar-benar aman bagi kesehatan manusia yang mengkonsumsinya serta dalam kontek supply dimana lahan pertanian organik dapat dilestarikan lingkungannya.

\section{PEMBAHASAN}

Pengembangan usaha tani organik, utamanya di Desa Berjo Kecamatan Ngargoyoso Kabupaten Karanganyar yang akan menjadi lokus kegiatan, didukung oleh beragam sumber daya pertanian yang terdapat di desa tersebut. Dengan adanya beragam sumber daya pertanian tersebut, Desa Berjo layak mengembangkan usaha pertanian organik. Hal ini juga didukung oleh adanya pengembangan pariwisata di desa tersebut sehingga desa tersebut berpotensi dikunjungi banyak wisatawan untuk menikmati berbagai daya tarik wisata yang ada, menikmati udara pegunungan yang segar, menikmati suasana dan pemandangan alam pegunungan yang indah, serta melakukan berbagai kegiatan wisata. Pertanian organik dapat menjadi salah satu daya tarik wisata alternatif dan dapat pula berfungsi sebagai kegiatan wisata alternatif yang dapat dilakukan wisatawan. Dengan demikian berbagai sumber daya pertanian tersebut dapat dikembangkan menjadi usaha pertanian organik yang diarahkan untuk dapat bersinergi dengan pengembangan pariwisata pedesaan di daerah tersebut sehingga hasilnya dapat meningkatkan perekonomian dan kesejahteraan masyarakat. 
Gambar 2: Hasil Pertanian di Kabupaten Karanganyar.
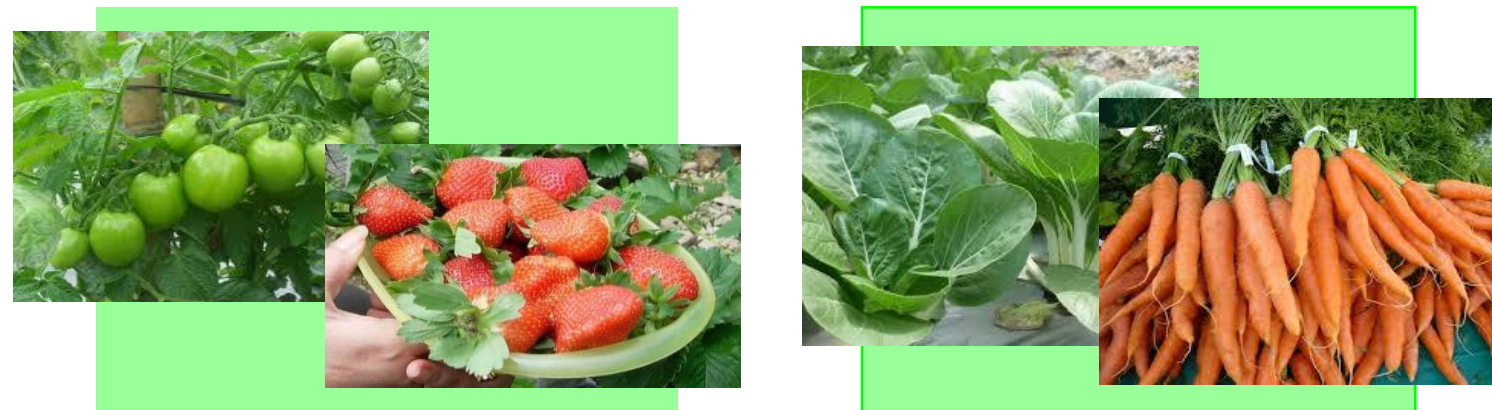

Akhir-akhir ini usaha pertanian organik sudah mulai dilaksanakan oleh masyarakat Desa Berjo Kecamatan Ngargoyoso Kabupaten Karanganyar meskipun usaha tersebut masih memiliki beberapa keterbatasan. Namun, terlepas dari berbagai keterbatasan yang ada, terdapat sisi positif yang perlu dimanfaatkan untuk mendukung usaha pertanian organik di desa tersebut. Salah satunya adalah telah dicanangkannya Desa Berjo sebagai desa wisata sejak tahun 2003. Desa Berjo merupakan desa yang memiliki beragam potensi wisata, baik alam maupun budaya, sehingga pengembangan Desa Berjo sebagai desa wisata memang tepat. Untuk mendukung pengembangan Desa Berjo sebagai desa wisata Pemerintah Kabupaten Karanganyar melalui beberapa instansi terkait seperti Dinas Pariwisata dan Kebudayaan Kabupaten Karanganyar, Badan Pemberdayaan Masyarakat dan Desa, serta dinas/instansi terkait lainnya, telah melakukan fasilitasi bagi masyarakat setempat sebagai "tuan rumah" yang dituntut untuk bisa memberikan layanan yang profesional dan berkualitas kepada "tamu" yang datang. Berbagai bidang dan sektor usaha yang berkaitan dengan pengembangan desa wisata antara lain adalah layanan boga dan penyediaan oleh-oleh. Salah satu usaha tani yang dapat dikembangkan untuk mendukung kegiatan wisata dan usaha wisata lainnya di desa tersebut adalah usaha pertanian organik. Pertanian organik dapat difokuskan pada pengolahan hasil pertanian organik untuk membuat makanan sehat bagi wisatawan. Di samping itu dapat juga dikembangkan penyediaan oleh-oleh berbasis pertanian organik untuk wisatawan.

Berbagai usaha tersebut di atas dapat dikelola oleh warga masyarakat setempat khususnya para petani, melalui pengembangan usaha tani organik. Namun demikian, pada saat ini masyarakat petani yang telah membuka usaha tani, yakni "Gemah Ripah" dan Kelompok Usaha Tani "Sumber Rejeki" masih menghadapi beberapa permasalahan dalam kaitannya dengan pengembangan pertanian organik sebagai salah satu bentuk usaha untuk meningkatkan perekonomian keluarga. Beberapa permasalahan yang teridentifikasi berkaitan dengan hal tersebut antara lain adalah sebagai berikut.

1. Keterbatasan pengetahuan dan keterampilan yang berkaitan dengan pengolahan, pengemasan, dan pemasaran hasil pertanian berupa buah dan sayur organik sebagai oleh-oleh wisata khas Desa Berjo Kecamatan Ngargoyoso Kabupaten Karanganyar Propinsi Jawa Tengah.

2. Keterbatasan kreativitas mengolah dalam berbagai ragam produk hasil pertanian buah dan sayur organik sebagai oleh-oleh wisata khas Desa Berjo Kecamatan Ngargoyoso Kabupaten Karanganyar Propinsi Jawa Tengah yang mudah dibawa oleh para wisatawan. 
3. Keterbatasan peralatan pengemasan yang sesuai standard kebersihan, kesehatan dan keamanan pangan serta yang dapat menarik minat wisatawan.

4. Keterbatasan manajemen pemasaran dan jejaring untuk meningkatkan daya tarik wisata organik Desa Berjo Kecamatan Ngargoyoso Kabupaten Karanganyar Propinsi Jawa Tengah.

Gambar 3: Pengemasan buah dan sayur yang masih sederhana di Desa Berjo

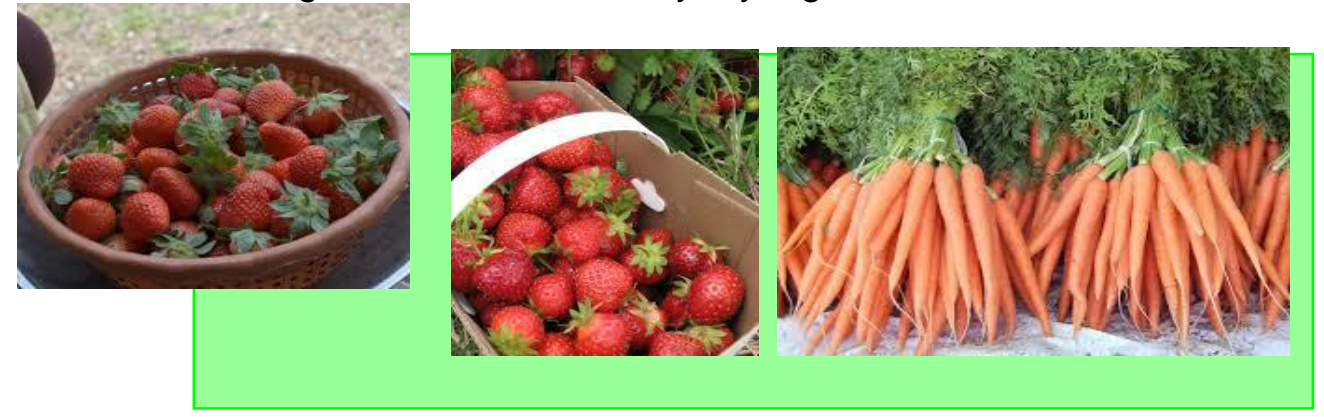

Di dalam menentukan permasalahan yang akan dicarikan solusi, tim PKM berdiskusi dengan mitra (pelaku usaha tani organik) untuk menyusun persoalan prioritas yang didasarkan pada empat permasalahan. Ke empat permasalahan yang dihadapi oleh petani organik adalah: Keterbatasan pengetahuan dan keterampilan yang berkaitan dengan pengolahan, pengemasan, dan pemasaran hasil pertanian berupa buah dan sayur organik sebagai oleh-oleh wisata khas Desa Berjo Kecamatan Ngargoyoso Kabupaten Karanganyar Propinsi Jawa Tengah; Keterbatasan kreativitas mengolah dalam berbagai ragam produk hasil pertanian buah dan sayur organik sebagai oleh-oleh wisata khas Desa Berjo Kecamatan Ngargoyoso Kabupaten Karanganyar Propinsi Jawa Tengah yang mudah dibawa oleh para wisatawan; Keterbatasan peralatan pengemasan yang sesuai standard kebersihan, kesehatan dan keamanan pangan serta yang dapat menarik minat wisatawan; dan Keterbatasan manajemen pemasaran dan jejaring untuk meningkatkan daya tarik wisata organik Desa Berjo Kecamatan Ngargoyoso Kabupaten Karanganyar Propinsi Jawa Tengah.

Di dalam menyelesaikan permasalahan/persoalan yang dihadapai mitra tersebut dibuat kesepakatan bersama antara mitra (Kelompok Usaha Tani "Gemah Ripah" dan Kelompok Usaha Tani "Sumber Rejeki") dengan Tim PKM dari Fakultas Pertanian Universitas Sebelas Maret. Kesepakatan tersebut menyebutkan bahwa untuk mengatasi masalah-masalah yang sudah diidentifikasi, tim PKM akan memberikan penyuluhan, pelatihan, dan pendampingan serta bantuan peralatan dan pembuatan website untuk meningkatkan pengetahuan dan keterampilan mitra (kelompok usaha tani) tentang pengolahan, pengemasan, dan pemasaran hasil pertanian buah dan sayur organik sebagai oleh-oleh wisata khas Desa Berjo. Lebih lanjut berbagai hal tersebut diarahkan untuk mendukung upaya pengembangan kompetensi petani agar mereka dapat meningkatkan perekonomian melalui berbagai usaha kreatif berbasis sumber daya pertanian di daerahnya.

\section{REFERENCES}

BAPPEDA (Badan Perencanaan Pembangunan Daerah) Kabupaten Karanganyar, 2013, Rencana Pembangunan Jangka Menengah Daerah (RPJMD) 2013 - 2018).

Badan Statistik Kabupaten Karanganyar, 2013, Kabupaten Karanganyar Dalam Angka Tahun 2012. 
Badan Usaha Milik Desa (BUMDes) Berjo, 2008, Profil Wisata Desa Berjo Kecamatan Ngargoyoso Kabupaten Karanganyar.

Razanur, Muhammad, 2013, Permasalahan pertanian organik di Indonesia, http://pertanianorgani.blogspot.com/ 